February 2005 • NREL/CP-520-37358

\title{
Performance Parameters for Grid-Connected PV Systems
}

B. Marion, J. Adelstein, and K. Boyle National Renewable Energy Laboratory

H. Hayden, B. Hammond, T. Fletcher, B. Canada, and D. Narang

Arizona Public Service Co.

D. Shugar, H. Wenger, A. Kimber, and L. Mitchell PowerLight Corporation

G. Rich and T. Townsend

First Solar

Prepared for the $31^{\text {st }}$ IEEE Photovoltaics Specialists Conference and Exhibition

Lake Buena Vista, Florida January 3-7, 2005
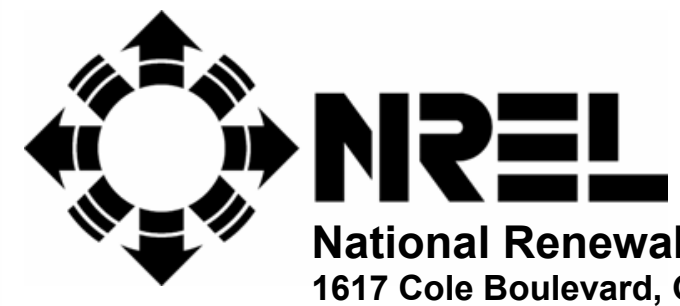

National Renewable Energy Laboratory

1617 Cole Boulevard, Golden, Colorado 80401-3393

303-275-3000 • www.nrel.gov

Operated for the U.S. Department of Energy

Office of Energy Efficiency and Renewable Energy

by Midwest Research Institute - Battelle

Contract No. DE-AC36-99-GO10337 


\section{NOTICE}

The submitted manuscript has been offered by an employee of the Midwest Research Institute (MRI), a contractor of the US Government under Contract No. DE-AC36-99G010337. Accordingly, the US Government and MRI retain a nonexclusive royalty-free license to publish or reproduce the published form of this contribution, or allow others to do so, for US Government purposes.

This report was prepared as an account of work sponsored by an agency of the United States government. Neither the United States government nor any agency thereof, nor any of their employees, makes any warranty, express or implied, or assumes any legal liability or responsibility for the accuracy, completeness, or usefulness of any information, apparatus, product, or process disclosed, or represents that its use would not infringe privately owned rights. Reference herein to any specific commercial product, process, or service by trade name, trademark, manufacturer, or otherwise does not necessarily constitute or imply its endorsement, recommendation, or favoring by the United States government or any agency thereof. The views and opinions of authors expressed herein do not necessarily state or reflect those of the United States government or any agency thereof.

Available electronically at http://www.osti.gov/bridge

Available for a processing fee to U.S. Department of Energy and its contractors, in paper, from:

U.S. Department of Energy

Office of Scientific and Technical Information

P.O. Box 62

Oak Ridge, TN 37831-0062

phone: 865.576 .8401

fax: 865.576.5728

email: mailto:reports@adonis.osti.gov

Available for sale to the public, in paper, from:

U.S. Department of Commerce

National Technical Information Service

5285 Port Royal Road

Springfield, VA 22161

phone: 800.553 .6847

fax: 703.605.6900

email: orders@ntis.fedworld.gov

online ordering: http://www.ntis.gov/ordering.htm 


\title{
Performance Parameters for Grid-Connected PV Systems
}

\author{
B. Marion, ${ }^{1}$ J. Adelstein, ${ }^{1}$ K. Boyle, ${ }^{1}$ H. Hayden, ${ }^{2}$ B. Hammond ${ }^{2}$ T. Fletcher, ${ }^{2}$ B. Canada, ${ }^{2}$ D. Narang, ${ }^{2}$ \\ D. Shugar, ${ }^{3}$ H. Wenger, ${ }^{3}$ A. Kimber, ${ }^{3}$ L. Mitchell, ${ }^{3}$ G. Rich, ${ }^{4}$ and T. Townsend ${ }^{4}$ \\ ${ }^{1}$ National Renewable Energy Laboratory, 1617 Cole Blvd., Golden, CO 80401 \\ ${ }^{2}$ Arizona Public Service Co., 1500 E. University Dr., Tempe, AZ 85281 \\ ${ }^{3}$ PowerLight Corporation, 2954 San Pablo Ave., Berkeley, CA 94702 \\ ${ }^{4}$ First Solar, 4050 E. Cotton Center Blvd. \#6-68, Phoenix. AZ 85040
}

\begin{abstract}
The use of appropriate performance parameters facilitates the comparison of grid-connected photovoltaic (PV) systems that may differ with respect to design, technology, or geographic location. Four performance parameters that define the overall system performance with respect to the energy production, solar resource, and overall effect of system losses are the following: final PV system yield, reference yield, performance ratio, and PVUSA rating. These performance parameters are discussed for their suitability in providing desired information for PV system design and performance evaluation and are demonstrated for a variety of technologies, designs, and geographic locations. Also discussed are methodologies for determining system a.c. power ratings in the design phase using multipliers developed from measured performance parameters.
\end{abstract}

\section{INTRODUCTION}

Accurate and consistent evaluations of photovoltaic (PV) system performance are critical for the continuing development of the PV industry. For component manufacturers, performance evaluations are benchmarks of quality for existing products. For research and development teams, they are a key metric for helping to identify future needs. For systems integrators and end customers, they are vital tools for evaluating products and product quality to guide future decision-making.

As the industry has grown, a clear need has arisen for greater use of and education about appropriate industrystandard performance parameters for PV systems. These performance parameters allow the detection of operational problems; facilitate the comparison of systems that may differ with respect to design, technology, or geographic location; and validate models for system performance estimation during the design phase. Industry-wide use of standard performance parameters and system ratings will assist investors in evaluating different proposals and technologies, giving them greater confidence in their own ability to procure and maintain reliable, high-quality systems. Standard methods of evaluation and rating will also help to set appropriate expectations for performance with educated customers, ultimately leading to increased credibility for the PV industry and positioning it for further growth.

Parameters describing energy quantities for the PV system and its components have been established by the International Energy Agency (IEA) Photovoltaic Power Systems Program and are described in the IEC standard 61724 [1]. (IEA task members have used these performance parameters to develop a database of operational and reliability performance [2]. The database contains information for several hundred PV systems and may be viewed at www.task2.org.)

Three of the IEC standard 61724 performance parameters may be used to define the overall system performance with respect to the energy production, solar resource, and overall effect of system losses. These parameters are the final PV system yield, reference yield, and performance ratio.

The final $P V$ system yield $Y_{f}$ is the net energy output $E$ divided by the nameplate d.c. power $P_{0}$ of the installed $\mathrm{PV}$ array. It represents the number of hours that the PV array would need to operate at its rated power to provide the same energy. The units are hours or $\mathrm{kWh} / \mathrm{kW}$, with the latter preferred by the authors because it describes the quantities used to derive the parameter. The $Y_{f}$ normalizes the energy produced with respect to the system size; consequently, it is a convenient way to compare the energy produced by $\mathrm{PV}$ systems of differing size:

$$
Y_{f}=\frac{E}{P_{0}} \quad(k W h / k W) \text { or (hours) }
$$

The reference yield $Y_{r}$ is the total in-plane irradiance $H$ divided by the $P V$ 's reference irradiance $G$. It represents an equivalent number of hours at the reference irradiance. If $G$ equals $1 \mathrm{~kW} / \mathrm{m}^{2}$, then $Y_{r}$ is the number of peak sunhours or the solar radiation in units of $\mathrm{kWh} / \mathrm{m}^{2}$. The $Y_{r}$ defines the solar radiation resource for the PV system. It is a function of the location, orientation of the PV array, and month-to-month and year-to-year weather variability:

$$
Y_{r}=\frac{H}{G} \quad \text { (hours) }
$$


The performance ratio $P R$ is the $Y_{f}$ divided by the $Y_{r}$. By normalizing with respect to irradiance, it quantifies the overall effect of losses on the rated output due to: inverter inefficiency, and wiring, mismatch, and other losses when converting from d.c. to a.c. power; PV module temperature; incomplete use of irradiance by reflection from the module front surface; soiling or snow; system down-time; and component failures:

$$
\mathrm{PR}=\frac{\mathrm{Y}_{\mathrm{f}}}{\mathrm{Y}_{\mathrm{r}}} \quad \text { (dimensionless) }
$$

PR values are typically reported on a monthly or yearly basis. Values calculated for smaller intervals, such as weekly or daily, may be useful for identifying occurrences of component failures. Because of losses due to $\mathrm{PV}$ module temperature, PR values are greater in the winter than in the summer and normally fall within the range of 0.6 to 0.8 . If $P V$ module soiling is seasonal, it may also impact differences in PR from summer to winter. Decreasing yearly values may indicate a permanent loss in performance.

The PVUSA rating method [3] uses a regression model and system performance and meteorological data to calculate power at PVUSA Test Conditions (PTC), where PTC are defined as $1000 \mathrm{~W} / \mathrm{m}^{2}$ plane-of-array irradiance, $20^{\circ} \mathrm{C}$ ambient temperature, and $1 \mathrm{~m} / \mathrm{s}$ wind speed. PTC differs from standard test conditions (STC) in that its test conditions of ambient temperature and wind speed will result in a cell temperature of about $50^{\circ} \mathrm{C}$, instead of the $25^{\circ} \mathrm{C}$ for STC. This is for a rack-mounted PV module with relatively good cooling on both sides of the module. For PV modules mounted close to the roof or integrated into the building with the airflow restricted, PTC will yield greater cell temperatures. Nordmann and Clavadetscher [4] report that PV module temperatures rise above ambient for fielded system ranging from $20^{\circ} \mathrm{C}$ to $52^{\circ} \mathrm{C}$ at $1000 \mathrm{~W} / \mathrm{m}^{2}$, with the largest temperature rise for an integrated façade. The difference between the nameplate d.c. power rating and the system PVUSA rating is an indication of the total system losses associated with converting d.c. module energy to a.c. energy. As with decreasing PR values, decreasing PVUSA ratings over time may indicate a permanent loss in performance.

\section{D.C. AND A.C. RATINGS}

The $Y_{f}$ is calculated by dividing the energy yield recorded with a utility $\mathrm{kWh}$ meter by the nameplate d.c. power rating. The nameplate d.c. power rating is determined by summing the module powers listed on the nameplates on the backsides of the individual PV modules in the PV array. The PV module power ratings are for STC of $1000 \mathrm{~W} / \mathrm{m}^{2}$ solar irradiance and $25^{\circ} \mathrm{C}$ cell temperature. Besides being easily determined, the nameplate d.c. power rating's use in the equation for $Y_{f}$ offers the advantage, as compared to the use of an a.c. power rating or conditions other than STC, of differentiating between systems with different d.c. to a.c. conversion efficiencies or different mounting-related $\mathrm{PV}$ module temperature environments. For example, if performance was with respect to an a.c. power rating, two systems might report the same $\mathrm{Y}_{\mathrm{f}}$, but have significantly different inverter efficiencies, or other loss mechanisms. Similarly, if performance was with respect to PTC, two systems might report the same $Y_{f}$, but have significantly different $P V$ module temperature-related losses because of how the $\mathrm{PV}$ modules are mounted or integrated into the building.

Although a nameplate d.c. power rating is used in $Y_{f}$ to report the normalized energy produced by an existing system, an a.c. power rating is essential when attempting to predict the energy a PV system will produce using models such as PVWATTS [5], PVDesignPro [6], or PVGRID [7]. Accurate energy predictions are crucial to the continued development of the photovoltaic industry because they set the investor's expectations for system performance and the associated economic return. The remainder of this section discusses a.c. power ratings and considerations in their determination.

PV systems may be assigned a.c. power ratings by accounting for: (1) losses in converting from d.c. to a.c. power, and (2) operating cell temperatures that are usually greater than $25^{\circ} \mathrm{C}$. In the first case, the nameplate d.c. power rating is multiplied by empirically determined derate factors to calculate an a.c. power rating at STC. In the second case, an additional derate can be applied for temperature other than STC. Finally, the PVUSA rating method may be used to assign an a.c. rating to an existing system with historical data.

To evaluate the accuracy of our empirical derate factors, PVUSA ratings were determined for 24 PowerLight PV systems (twenty single-crystalline silicon, two multicrystalline silicon, and two amorphous silicon) located throughout the United States. These ratings were then compared to the a.c. ratings for the same systems calculated by using the derate method and the derate factors from Table 1. All derate factors in Table 1 were estimated from measured losses and component specifications. The typical overall derate factor at nominal operating cell temperature (NOCT) is 0.731 , representing a loss of $26.9 \%$ from the nameplate d.c. rating.

Table 1. Derate Factors for A.C. Power Rating

\begin{tabular}{lcc}
\hline Item & Typical & Range \\
\hline PV module nameplate d.c. rating & 1.00 & $0.85-1.05$ \\
Initial light-induced degradation & 0.98 & $0.90-0.99$ \\
d.c. cabling & 0.98 & $0.97-0.99$ \\
Diodes and connections & 0.995 & $0.99-0.997$ \\
Mismatch & 0.98 & $0.97-0.985$ \\
Power-conditioning unit (inverter) & 0.96 & $0.93-0.96$ \\
Transformers & 0.97 & $0.96-0.98$ \\
a.c. wiring & 0.99 & $0.98-0.993$ \\
Soiling & 0.95 & $0.75-0.98$ \\
Shading & 1.00 & $0.0-1.00$ \\
Sun-tracking & 1.00 & $0.98-1.00$ \\
Availability of system & 0.98 & $0.0-0.995$ \\
\hline Overall at STC & 0.804 & $0.62^{*}-0.92$ \\
\hline Temperature (at NOCT $\left.=45^{\circ} \mathrm{C}\right)$ & 0.91 \\
\hline Overall at NOCT & 0.731 \\
\hline${ }^{*}$ Does not include soiling, shading, tracking, or availability losses
\end{tabular}

*Does not include soiling, shading, tracking, or availability losses 
For the initial comparison, all "typical" derate factors from Table 1 were used, except for the temperature derate factors that were determined using the manufacturers' power correction factors for temperature and NOCTs of $45^{\circ} \mathrm{C}$. The results of the comparison using this derate method are shown in Fig. 1. The derate method a.c. ratings were as much as $19 \%$ greater than the PVUSA rating, and the standard deviation of the differences was $7 \%$. In Fig. 1, the measured loss is the difference between the nameplate d.c. rating and the PVUSA rating. The design loss is the difference between the nameplate d.c. rating and the a.c. rating calculated using the derate method. For an accurate design, the measured loss and design loss will be very close. The measured and design losses are expressed as percentages for ease of comparison.

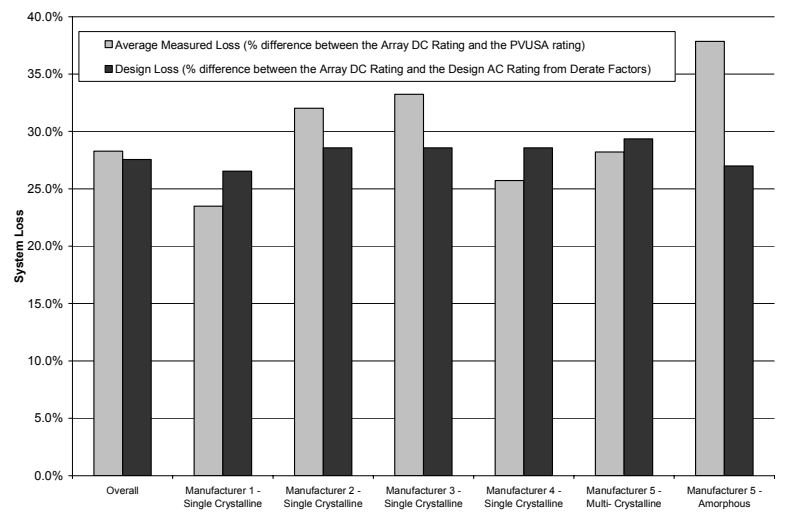

Fig. 1. Design and measured losses using typical derate factors, except for the temperature derate factor, which was manufacturer specific.

Current-voltage (I-V) curve testing of $\mathrm{PV}$ modules used in these 24 systems revealed that the accuracy of the nameplate ratings varied by manufacturer, and for certain manufacturers the accuracy varied by product. Some PV modules produced as much as $4 \%$ more than specified, whereas others were as much as $12 \%$ less than specified [8].

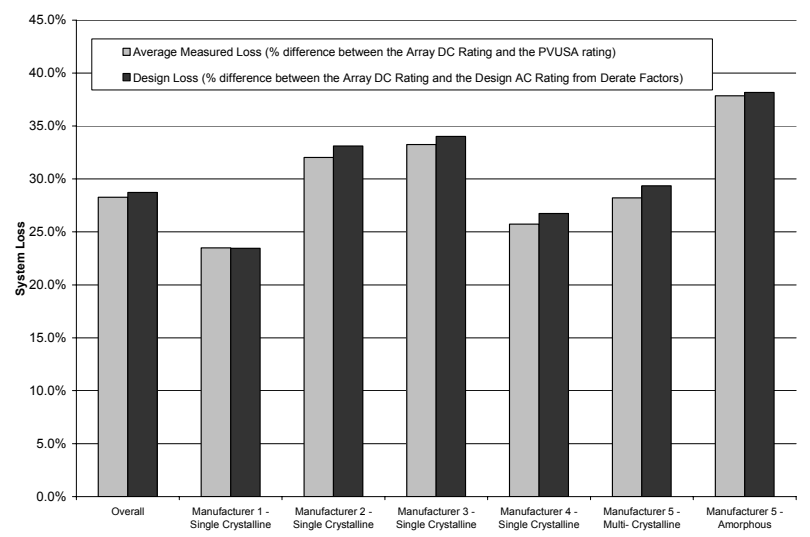

Fig. 2. Design and measured losses using typical derate factors, except for the temperature derate factor and the PV module nameplate d.c. rating derate factor, which were manufacturer specific.
Consequently, for the second comparison, results were significantly improved by using a derate factor to account for the accuracy of the manufacturer's nameplate d.c. ratings, as detailed in the first row of Table 1. Compared to the PVUSA ratings, the a.c ratings calculated using a derate method including a factor for manufacturer's nameplate rating were within $\pm 5 \%$, with a standard deviation of the differences of $2 \%$. Figure 2 illustrates these results. Although not evaluated, still better agreement might have been achieved by using systemspecific derate and NOCT values instead of typical values.

\section{INFLUENCE OF WEATHER}

Variations in solar radiation and ambient temperature from month-to-month and year-to-year influence the performance parameters. Therefore, it is important to identify which performance parameters are suitable for which system evaluations based on their weatherdependence. The $Y_{f}$ is influenced the most because of its dependency on solar radiation. The PR is influenced less because values are normalized with respect to solar radiation, but values are influenced by seasonal variations in temperature. The PVUSA a.c power ratings at PTC are influenced the least because the method performs the regression using solar radiation, ambient temperature, and wind speed values. Small variations in PVUSA method a.c power ratings can be attributed to the range of values over which the regression is performed, nonlinearities in $\mathrm{PV}$ module and inverter performance, and variations in solar spectrum.

To illustrate the extent to which the performance parameters might be influenced by weather, $P V$ system performance was modeled using PVFORM [9] for a 30year period. The hourly solar radiation and meteorological data input to PVFORM was for the Boulder, CO, station in the National Solar Radiation Data Base [10]. PV system specifications were the same as the PV system located on the roof of the Solar Energy Research Facility (SERF) at the National Renewable Energy Laboratory (NREL): single-crystalline silicon PV modules, nameplate d.c. power rating of $7420 \mathrm{~W}, \mathrm{PV}$ array tilt angle of $45^{\circ}$, and $\mathrm{PV}$ array azimuth angle of $22^{\circ}$ east of south. Using modeled, instead of measured, data permitted the influence of weather to be evaluated over a longer period of time and eliminated the need to carefully screen erroneous data or data collected when the system was inoperative, or to account for any performance degradation that occurred.

Using the modeled data for the 30-year period, monthly and yearly performance parameters and PVUSA a.c power ratings at PTC were calculated. The results are shown in Fig. 3. If weather had no influence, the values would all reside on a horizontal line, but that is clearly not the case. As expected, $Y_{f}$ shows the greatest variability and the PVUSA a.c power rating at PTC shows the least. Although not shown, the variability of $Y_{r}$ is similar to $Y_{f}$ because of $Y_{f}$ 's dependence on solar irradiance. $P R$ values exhibit the influence of temperature, with smaller values in summer than winter. For yearly values, 95\% confidence intervals, determined as twice the standard 
deviations, are shown. The confidence interval of $\pm 8.4 \%$ for $Y_{f}$ means that $95 \%$ of the yearly values should be within $8.4 \%$ of the average yearly value. As indicated by the scatter of data, monthly values are more variable, resulting in greater confidence intervals than for the yearly values. Although PR varies from summer to winter, the yearly values are consistent with a confidence interval of $\pm 1.2 \%$, which is only slightly greater than the confidence interval of $\pm 0.7 \%$ for yearly values of PVUSA a.c power ratings at PTC. (Because the PVUSA ratings are determined using a month of data, the yearly value was determined as the average of the 12 monthly values.) Consequently, both PVUSA a.c power ratings at PTC and yearly PR values should be able to detect degradation of system performance over time.

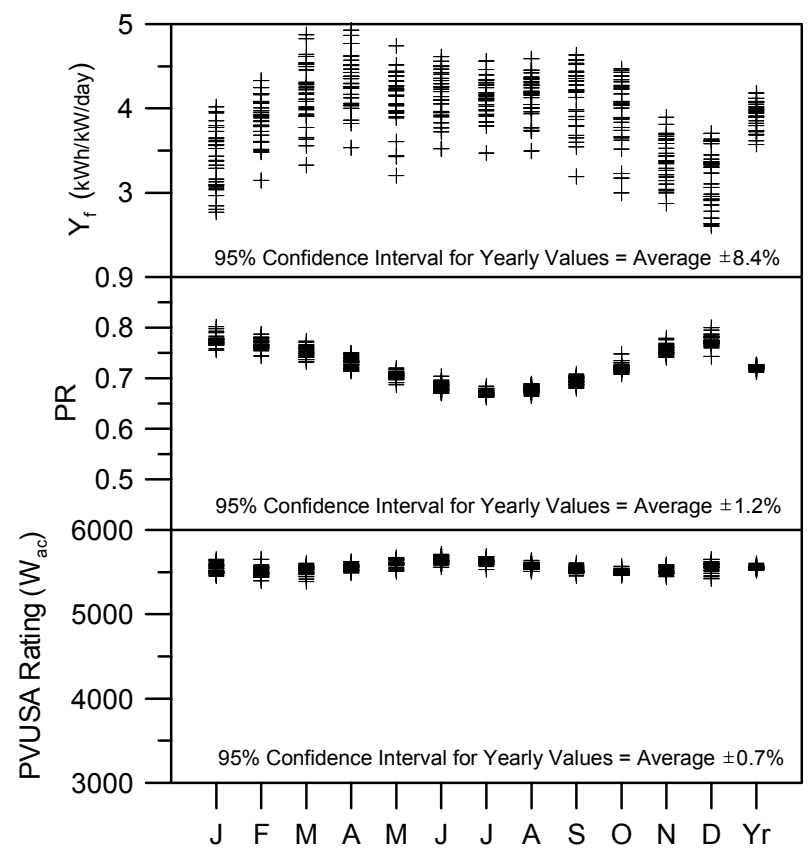

Fig. 3. Monthly and yearly $Y_{f}, P R$, and PVUSA a.c power rating at PTC from PV performance data modeled over a 30-year period show the influence of weather variability.

\section{EXAMPLE RESULTS FOR $\mathbf{Y}_{\boldsymbol{f}}$}

Arizona Public Service Co. operates numerous gridconnected PV systems within its service territory [11]. Table 2 contains a listing of some of these systems and their $Y_{f}$ values for the 12-month period of September 2003 through August 2004. Because the solar resource $\left(Y_{r}\right)$ is greater for the single-axis tracking systems, their $Y_{f}$ values are larger than those for the non-tracking systems.

For the single-axis tracking systems, Fig. 4 shows monthly and yearly $Y_{f}$ values for the 12-month period. $Y_{f}$ values were largest for the Airport MTA2 and the Yucca power plant systems, primarily because their PV modules' performance met their nameplate expectations. The other systems performed at a lower level because of a combination of factors: PV module performance, inverter efficiency, and operational problems. Specifically, for the
Airport MTB1 system, the inverter operated poorly until August, when all its performance issues had been resolved. The Gilbert Nature Center system experienced frequent inverter faults, and in August a conductor failed, rendering the system inoperable or operating at reduced power for most of the month.

Table 2. Arizona Public Service PV Systems and Their $Y_{f}$ for September 2003 Through August 2004.

\begin{tabular}{|c|c|c|c|}
\hline System Name & Location & $\begin{array}{c}\text { Size } \\
\left(k W_{d c}\right)\end{array}$ & $\begin{array}{c}\mathrm{Y}_{\mathrm{f}} \\
(\mathrm{kWh} / \mathrm{kW})\end{array}$ \\
\hline \multicolumn{4}{|c|}{ Single-Axis Tracking, North-South Horizontal Axis } \\
\hline Embry Riddle & Prescott & 228.50 & 1906 \\
\hline Gilbert Nature Ctr. & Tempe/Mesa & 144.00 & 1682 \\
\hline Ocotillo 1 & Tempe & 94.47 & 1806 \\
\hline Airport MTA2 & Prescott & 121.00 & 2118 \\
\hline Airport MTA7 & Prescott & 151.20 & 1882 \\
\hline Airport MTB1 & Prescott & 151.20 & 1406 \\
\hline Airport MTB2 & Prescott & 151.20 & 1807 \\
\hline Airport MTB3 & Prescott & 151.20 & 1861 \\
\hline Airport MTB5 & Prescott & 117.60 & 1869 \\
\hline Water Tanks-East & Scottsdale & 153.60 & 1986 \\
\hline Water Tanks-West & Scottsdale & 144.00 & 2020 \\
\hline Yucca Pwr. Plant & Yuma & 121.00 & 2147 \\
\hline \multicolumn{4}{|c|}{ Non-Tracking, Horizontal } \\
\hline Star Parking & Tempe & 5.04 & 1345 \\
\hline \multicolumn{4}{|c|}{ Non-Tracking, South-Facing with Tilt Equal to Latitude } \\
\hline Challenger & Peoria & 2.28 & 1593 \\
\hline Desert & Lake Pleasant & 2.28 & 1461 \\
\hline
\end{tabular}

The $Y_{f}$ normalizes performance with respect to system size; consequently, it is useful for comparing systems of different size to quantify benefits of design, components, or locations. But unlike the $P R$, the $Y_{f}$ values do not correct for the variability of solar radiation, and therefore, are not as useful for identifying operational problems. The exception is side-by-side operation of systems of identical design, such as the Arizona Public Service single-axis trackers at the Prescott airport. For this situation, we can assume that all systems have essentially the same solar resource $\left(Y_{r}\right)$, and that any operational problem may be detected by comparing a system's $Y_{f}$

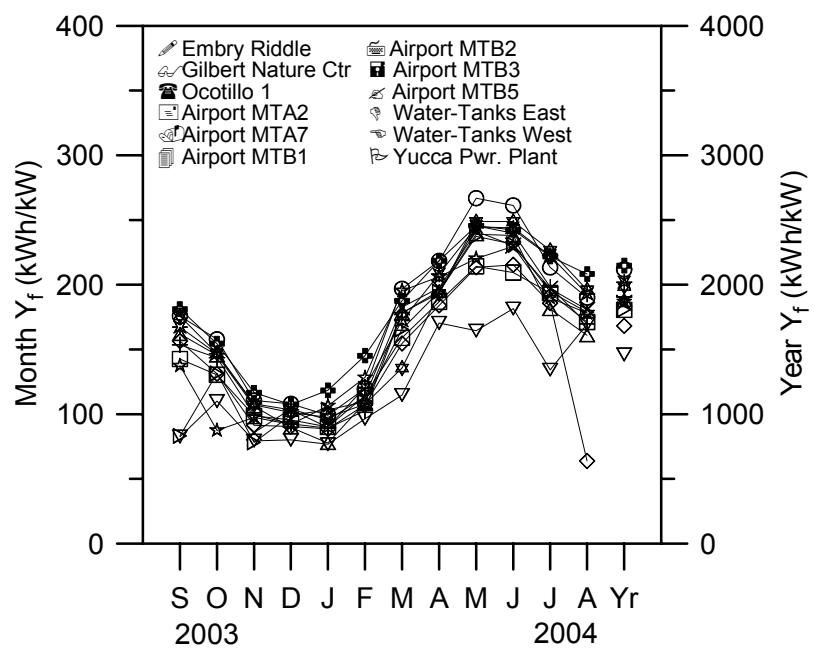

Fig. 4. Monthly and yearly $Y_{f}$ for Arizona Public Service singleaxis trackers for September 2003 through August 2004. 
against that of the other systems. For a single system, a similar strategy might be used by dividing it into two or more subsystems, with each having their own inverter and a.c. metering.

\section{EXAMPLE RESULTS FOR PR}

The PR is a dimensionless quantity that indicates the overall effect of losses on the rated output. By itself, it does not represent the amount of energy produced, because a system with a low PR in a high solar resource location might produce more energy than a system with a high PR in a low solar resource location. However, for any given system, location, and time; if a change in component or design increases the $P R$, the $Y_{f}$ increases accordingly. $P R$ values are useful for determining if the system is operating as expected and for identifying the occurrence of problems due to inverter operation (faults/failures, peakpower tracking, software/control), circuit-breaker trips, solder-bond failures inside PV module junction boxes, diode failures, inoperative trackers, shading, snow, soiling, long-term PV system degradation, or other failures. Large decreases in PR indicate events that significantly impact performance, such as inverters not operating or circuitbreaker trips. Small or moderate decreases in PR indicate that a less severe problem exists. The PR can identify the existence of a problem, but not the cause. The cause of the problem requires further investigation, which may include a site visit by maintenance personnel. Decreases in PR from soiling or long-term PV system degradation may not be readily evident unless viewed over months, or years in the case of the latter. Decreases from soiling are site- and weather-dependent, with greater soiling (up to $25 \%$ for some California locations) for high-traffic, highpollution areas with infrequent rain.

For 2001, Fig. 5 presents daily, weekly, and monthly PR values for the NREL SERF PV system described in a previous section. For most of the year, the PR values are consistent with those modeled for the same system and shown in Fig. 1. But for winter and spring months, PR values are lower for days coinciding with

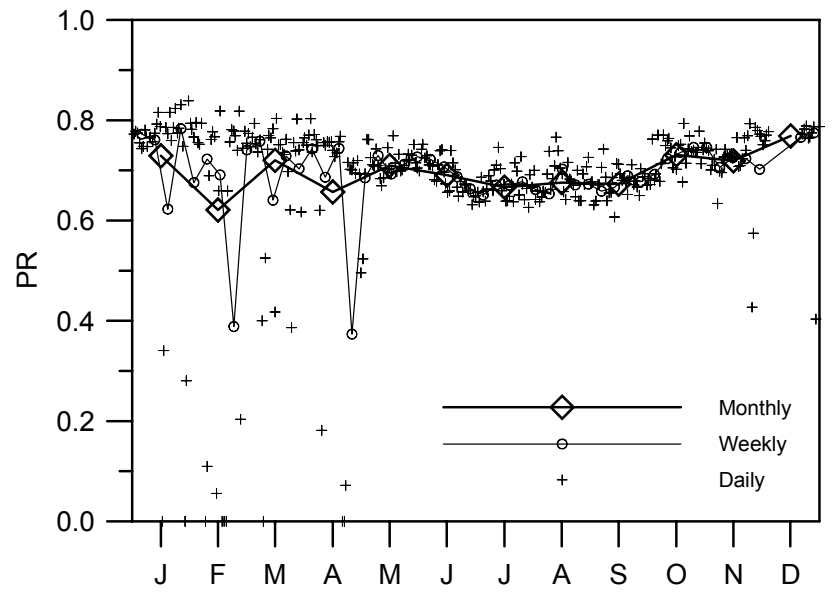

Fig. 5. Daily, weekly, and monthly PR values for the NREL SERF PV system for 2001. logbook entries reporting snowfall and for three days in February when the system was off. Depending on the amount of snow, daily PR values as low as zero occurred. The influence of snow is also evident in the weekly and monthly PR values, but to a lesser extent.

As an example of using PR to measure long-term changes in performance, Fig. 6 presents-for three PV systems - the linear least-square fits of monthly PR values over a period of several years. For comparison, results using the PVUSA method are also shown. Both methods show similar degradation rates, even though they use somewhat different input data. Whereas the calculation of PR uses all values of irradiance, the PVUSA method restricts irradiance values to $800 \mathrm{~W} / \mathrm{m}^{2}$ or above. To examine only the effects of long-term performance changes, both methods excluded data when the a.c. power value indicated the system was not operating. If instead the intent had been to evaluate overall system performance, data would not have been excluded and values would have been less. The results depicted in Fig. 6 are an example of using PR to measure performance changes over time, and are not meant as a definitive analysis of a PV technology's long-term performance for Denver or any other location. The relative performance of the three systems was influenced by using inverters with different conversion efficiencies

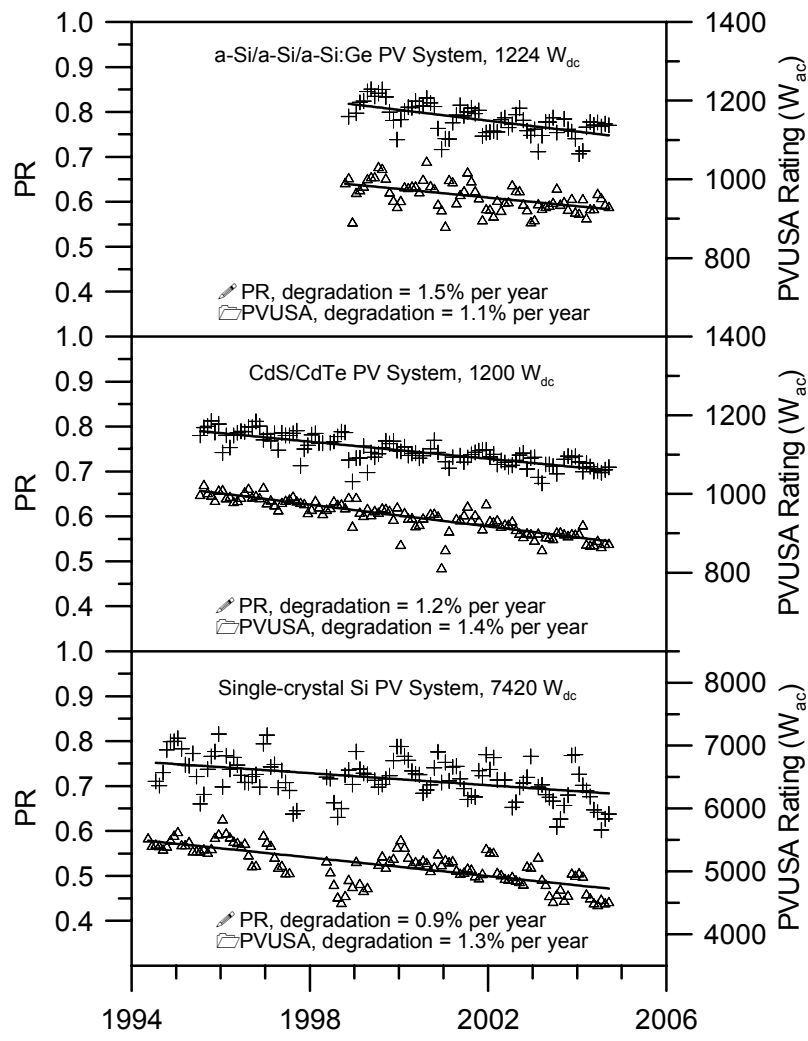

Fig. 6. Long-term degradation rates for three PV systems at NREL from monthly values of PR and PVUSA ratings. Upper regression lines from monthly $P R$ values shown by + symbols. Lower regression lines from monthly PVUSA values shown by $\Delta$ symbols. 
and operating characteristics. Also, the reliability of these small systems may not be representative of that of larger systems, and performance changes may have been different if tested in a different climate or location. For the system using the a-Si/a-Si/a-Si:Ge PV modules, data collection began after being deployed for several months and their initial performance degradation had occurred.

\section{SUMMARY AND FUTURE WORK}

Three performance parameters may be used to define the performance of grid-connected PV systems: final PV system yield $Y_{f}$, reference yield $Y_{r}$, and performance ratio $P R$. The $Y_{f}$ and $P R$ are determined using the nameplate d.c. power rating. The $Y_{f}$ is the primary measure of performance and is expressed in units of $\mathrm{kWh} / \mathrm{kW}$. It provides a relative measure of the energy produced and permits comparisons of PV systems of different size, design, or technology. If comparisons are made for different time periods or locations, it should be recognized that year-to-year variations in the solar resource will influence $Y_{f}$. The PR factors out solar resource variations by dividing $Y_{f}$ by the solar radiation resource, $Y_{r}$. This provides a dimensionless quantity that indicates the overall effect of losses and may be used to identify when operational problems occur or to evaluate long-term changes in performance. As part of an operational and maintenance program, the PR may be used to identify the existence of performance issues.

To further encourage the use of common reporting and design practices for PV systems, future activities should include: (1) additional work to gain support for an industry-standard set of performance parameters and system derating factors, (2) additional measurements for verifying individual derate factors (e.g., inverter, transformer, wiring, soiling,). Although using an overall derate factor yielded ratings close to that of the PVUSA method, a better knowledge of the individual derate factors would provide closer agreement and identify areas to improve system performance, and (3) development of a "Buyer's Guide" to explain performance parameters and system rating factors to potential investors and describe which system aspects are the biggest drivers of performance (e.g., inverter efficiency, module efficiency, reliability, performance degradation rate, system siting).

\section{REFERENCES}

[1] IEC, "Photovoltaic System Performance MonitoringGuidelines for Measurement, Data Exchange, and Analysis, IEC Standard 61724," Geneva, Switzerland, 1998.

[2] U. Jahn and W. Nasse, "Performance Analysis and Reliability of Grid-Connected PV Systems in IEA Countries," Proceedings of the $3^{\text {rd }}$ World Conference on PV Energy Conversion, Osaka, Japan, 2003.

[3] R. Dows, "PVUSA Procurement, Acceptance, and Rating Practices for Photovoltaic Power Plants," PG\&E Co. Report \#95-30910000.1, Sept. 1995.
[4] T. Nordmann and L. Clavadetscher, "Understanding Temperature Effects on PV System Performance," Proceedings of the $3^{\text {rd }}$ World Conference on PV Energy Conversion, Osaka, Japan, 2003.

[5] B. Marion and M. Anderberg. "PVWATTS-An Online Performance Calculator for Grid-Connected PV Systems," Proceedings of the ASES Solar 2000 Conference, June 16-21, 2000, Madison, WI.

[6] "PVDesign Pro User's Manual," Maui Solar Software Corporation, 1988.

[7] H. Wenger, "PVGrid User's Manual," PowerLight Corporation, 1990.

[8] A. Detrick, A. Kimber, and L. Mitchell, "Performance Evaluation Standards for Photovoltaic Modules \& Systems," Proceedings of the $31^{\text {st }}$ IEEE Photovoltaic Specialists Conference, Lake Buena Vista, FL, 2005 (in press).

[9] D. Menicucci and J. Fernandez, "User's Manual for PVFORM: A Photovoltaic System Simulation Program for Stand-Alone and Grid-Interactive Applications," SAND850376, Albuquerque, NM: Sandia National Laboratories, 1988.

[10] NSRDB Vol. 1, "User's Manual-National Solar Radiation Data Base (1961-1990)," Golden, CO: National Renewable Energy Laboratory, 1992.

[11] L. Moore, H. Post, H. Hayden, S. Canada, and D. Narang, "Photovoltaic Power Plant Experience at Arizona Public Service: A 5-Year Assessment," Progress in Photovoltaics: Research and Applications 2005; (in press). 


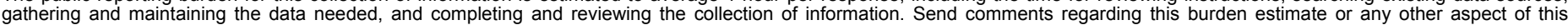

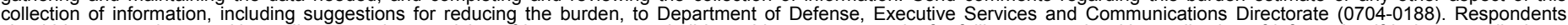

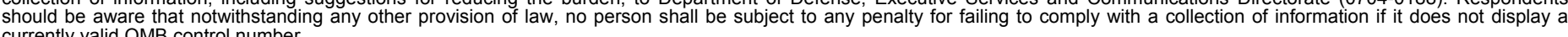

PLEASE DO NOT RETURN YOUR FORM TO THE ABOVE ORGANIZATION.

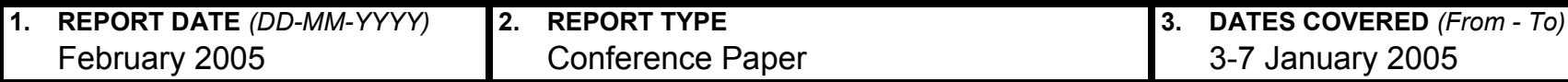

4. TITLE AND SUBTITLE

Performance Parameters for Grid-Connected PV Systems 5a. CONTRACT NUMBER

DE-AC36-99-GO10337

5b. GRANT NUMBER

5c. PROGRAM ELEMENT NUMBER

5d. PROJECT NUMBER

NREL/CP-520-37358

5e. TASK NUMBER

PVC57101

5f. WORK UNIT NUMBER
7. PERFORMING ORGANIZATION NAME(S) AND ADDRESS(ES)

National Renewable Energy Laboratory, 1617 Cole Blvd., Golden, CO 80401-3393

Arizona Public Service Co., 1500 E. University Dr., Tempe, AZ 85281

PowerLight Corporation, 2954 San Pablo Ave., Berkeley, CA 94702

First Solar, 4050 E. Cotton Center Blvd. \#6-68, Phoenix. AZ 85040

9. SPONSORING/MONITORING AGENCY NAME(S) AND ADDRESS(ES)
8. PERFORMING ORGANIZATION REPORT NUMBER

NREL/CP-520-37358

\section{DISTRIBUTION AVAILABILITY STATEMENT}

National Technical Information Service

U.S. Department of Commerce

5285 Port Royal Road

Springfield, VA 22161

13. SUPPLEMENTARY NOTES

\section{ABSTRACT (Maximum 200 Words)}

The use of appropriate performance parameters facilitates the comparison of grid-connected photovoltaic (PV) systems that may differ with respect to design, technology, or geographic location. Four performance parameters that define the overall system performance with respect to the energy production, solar resource, and overall effect of system losses are the following: final PV system yield, reference yield, performance ratio, and PVUSA rating. These performance parameters are discussed for their suitability in providing desired information for PV system design and performance evaluation and are demonstrated for a variety of technologies, designs, and geographic locations. Also discussed are methodologies for determining system a.c. power ratings in the design phase using multipliers developed from measured performance parameters.

\section{SUBJECT TERMS}

PV; performance parameters; grid-connected systems; energy production; solar resource; system yield; reference yield; performance ratio; PVUSA rating; a.c. power ratings

\begin{tabular}{l|l|l|l|l|}
\hline 16. SECURITY CLASSIFICATION OF: & 17. LIMITATION \\
OF ABSTRACT & 18. NUMBER \\
OF PAGES \\
$\begin{array}{l}\text { a. REPORT } \\
\text { Unclassified }\end{array}$ & $\begin{array}{c}\text { b. ABSTRACT } \\
\text { Unclassified }\end{array}$ & $\begin{array}{l}\text { c. THIS PAGE } \\
\text { Unclassified }\end{array}$ & UL & \\
\end{tabular}

19a. NAME OF RESPONSIBLE PERSON

19b. TELEPHONE NUMBER (Include area code) 